DOI: https://doi.org/10.47405/mjssh.v6i4.760

\begin{tabular}{|c|c|}
\hline+5 & Malaysian Journal of Social Sciences and Humanities (MJSSH) \\
\hline Malaysian Journal of & Volume 6, Issue 4, April 2021 \\
\hline $\begin{array}{l}\text { Humanities } \\
\text { (Mu-ssh) }\end{array}$ & e-ISSN : 2504-8562 \\
\hline & $\begin{array}{l}\text { Journal home page: } \\
\text { www.msocialsciences.com }\end{array}$ \\
\hline
\end{tabular}

\title{
Exploration of Challenges Among Gifted and Talented Children
}

\author{
Abdul Rashid Abdul Aziz ${ }^{1}$, Nor Hamizah Ab Razak' ${ }^{1}$, Rezki Perdani Sawai ${ }^{1}$, Mohd Faizal Kasmani' ${ }^{1}$, \\ Mohamad Isa Amat' ${ }^{1}$, Amin Al Haadi Shafie ${ }^{1}$ \\ ${ }^{1}$ Fakulti Kepimpinan dan Pengurusan, Universiti Sains Islam Malaysia (USIM)
}

Correspondence: Abdul Rashid Abdul Aziz (rashid@usim.edu.my)

\begin{abstract}
Most gifted students love to study, work hard to complete cognitive tasks, and wanted to have more difficult subjects for enhancing their intellectual capability. However, they are unable to do so in their regular classes even in their special gifted group. Some of the challenges faced by gifted and talented students are teachers' stigma, negative peer attitudes, difficulty understanding others, problems related to perfectionism, as well as impatience and intolerance. Thus, there is a dire need to cater the social and emotional issues of these students. Counselors may be unaware and unable to respond to these concerns because they are not well-trained to counsel this unique population. Therefore, this study aims to investigate the characteristics of gifted and talented students, challenges that they face and the need for counseling approaches to address all these issues to unleash the learning and development of gifted students.
\end{abstract}

Keywords: counseling services, gifted, talented, children

\section{Introduction}

Early childhood educators and family members have mutual goals to develop children's capacity and passion for learning to the fullest potential. In addition, research indicates that an interactive and responsive environment in early childhood supports both cognitive and affective growth and establishes a pattern of successful learning that can continue throughout children's lives (Clark, 2002). Young gifted students experience school in a variety of ways. They become bored in classrooms where they are not challenged. In addition, they can develop disruptive behaviors or underachieve in order to feel accepted by their classmates or teachers. According to the National Association of Gifted Students (NAGC), gifted students need provisions to help them make positive progress in their learning as well as challenging educational experiences that provide opportunities for young gifted students to make cognitive growth are limited (NAGC, 2006). Young gifted students may develop feelings of vulnerability when they are criticized or laughed at for viewing their world differently. Each young gifted student is different. One set of characteristics cannot describe every unique student. Besides, gifted children learned in stimulating, student-centered learning environment where there was a choice and ownership. They learned when they had opportunities to work with other gifted students, when they interacted with other students in their class and when they had opportunities to work independently. Gifted students also learned when their parents provided home experiences that stimulated and extended their learning. Furthermore, gifted students learn when they can direct their learning and the important factor is realizing that although gifted are highly skilled in some ways, they may need teacher support and instruction in other ways (Buckner, 2009). 


\section{Gifted and Talented Children in Malaysia}

In Malaysia, the national association was established in 1987 to advocate for the needs of gifted and talented children. The function of National Association of Gifted Children Malaysia (NAGC) is similar to other NAGC charities around the world. NAGC Malaysia provides support for parents of children with high learning potential regardless of circumstance, age and background. The estimated population of gifted Malaysians between the ages 0-14 years is 8.9 million. If 2 percent of that figure are gifted (the standard common definition of intellectual giftedness is two standard deviations above average IQ, or 98th percentile, or top 2 percent of the population). If 2 percent of 8.9 million children are gifted, then it would be about 178,000. Basically, the aims of the NAGC Malaysia are to assist by all possible means children with outstanding gifts and talents to fulfill their potential and to give support to parents, teachers and others professionally concerned with their development. NAGC Malaysia specific objectives are; 1) Serve as a public advocate for the needs of gifted child; 2) Provide opportunities for parents of gifted children to meet, share and discuss their problems and to consult specialists on education and other matters; 3) Promote research and development of the nature and education of gifted children; 4) Disseminate information to educationists, parents and the general public concerning the nature and education of gifted children; 5) Encourage and assist the development of local and state organizations to support the education of gifted children.

The study of gifted and talented children is gaining attention in the world of education. However, studies in this group usually focus on discussing cognitive developments and ignore aspects of their social and emotional needs (Rorlinda et al., 2016). Generally gifted and talented children are often thought to have no problem in whatever they do. This is because the group shows high academic achievement and potential in various fields, especially in academics, creative, leadership, visual arts, performance when compared to normal children of their age (Fisher \& Kennedy, 2016; Mc Eachern, 2001). In fact, the school also considers this group of children does not need to be given special psychological guidance (Gallagher \& Gallagher, 1994). This is due to the assumption that the interpersonal abilities possessed by this group are able to overcome the problems or difficulties they are experiencing (Delisle, 1985). However, research by psychologists found that gifted and talented children who were known as individuals with high cognitive abilities, creativity and task commitment (Rorlinda et al., 2016; Renzulli, 1997), were also found to have frequent experiences related to social and emotional problems (Versteynen, 2013; Robinson, 2006; Abu Yazid \& Aliza, 2009; Aliza \& Hamidah, 2009; Rosadah, 2004).

As children with high cognitive abilities, not every gifted and talented student have age-appropriate emotional development. Often, they lack understanding that others sometimes act emotionally rather than logically. This can result in treating others as stupid, which can endanger gifted teens not only socially but also emotionally. Likewise, the myths relating to gifted and talented children who are stable and do not face any problems of psychological aspect have long been rejected (Abu Yazid \& Aliza, 2009; Rosadah, 2004). This explains that gifted and talented children are also like other normal children who do not escape experiencing psychological problems which are even more significant due to factors such as developmental mismatches between mental and physical ages or better known as asynchronous development (Rorlinda et al., 2016), extreme perfectionism (Abu Yazid \& Aliza Alias, 2009), non-stimulating environments ( $\mathrm{Ng} \&$ Sandiyao, 2005) which affect their self-development and contribute to social and emotional problems (Rorlinda et al., 2017; Blaas, 2014). Therefore, these gifted and talented children need observation not only on intellectual aspects but also on learning and deep understanding of their psychological aspects. Among the units that are able to contribute to the psychological development of gifted and talented children are guidance and counseling services (Abu Yazid \& Bakar \& Zulkarnain, 2018; Rafidah \& Noriah, 2013; Noriah \& Abu Yazid, 2010). Thus, the study on exploration of the needs and challenges for this unique population is in dire needs.

\section{Literature Review}

\section{Definition of Gifted and Talented Children}


Researchers and educators differ in how they define giftedness. Traditionally, researchers have defined giftedness as high general intelligence as measured by a high global IQ score within above-average intelligence (usually defined as an IQ of 130 or higher) and superior talent in some domain (Hollingworth, 1942). According to Silverman (1997), Giftedness is asynchronous development in which advanced cognitive abilities and heightened intensity combine to create inner experiences and awareness that are qualitatively different from the norm. This asynchrony increases with higher intellectual capacity. The uniqueness of the gifted renders them particularly vulnerable and requires modifications in parenting, teaching and counseling in order for them to develop optimally. Many definitions of giftedness have developed and evolved. Marland (1972), the U.S. Commissioner of Education, defined gifted and talented students as;
"Those identified by professionally qualified persons who by virtue of outstanding abilities are capable of high performance. These are children who require differentiated programs and services beyond those normally provided by the regular school program in order to realize their contributions to self and society."

However, The Minnesota Department of Education has established the following definition of gifted and talented children which gifted is defined as youth or students with outstanding abilities, identified at preschool, elementary and secondary levels. These students are capable of high performance when compared to others of similar age, experience and environment, and represent the diverse populations of our communities. These are students whose potential requires differentiated and challenging educational programs and services beyond those provided in the general school program. Basically, gifted and talented children are capable of high performance include those with demonstrated achievement and potential ability in any of the following areas: 1) General intellectual aptitude, 2) Specific academic aptitude, 3) Creative or productive thinking, 4) Leadership ability and 5) Visual and performing arts.

\section{Characteristic of Gifted Children}

The characteristics of gifted and talented children have been observed over many years. This kind of child stands out as different from the norm and the list of characteristics is one way of understanding how these children are different and what makes them so. These characteristics do not necessarily guarantee success for all gifted children. For some their gifted personality, the desire for perfection, pressure from parents and teachers, the envy, taunts, bullying and the isolation they may feel from their peers can combine to produce within them an emotionally fragile state. Other than that, most discussions of cognitive characteristics focus on the differences between gifted and average children. Metacognitive characteristics involve thinking about one's own ways of knowing remembering and understanding. They include metacognitive knowledge and awareness, meta-memory, insight and regulation of cognition. Cheng (1993) stated that there is both theoretical and empirical evidence for superior metacognitive ability being an essential component of giftedness. Winner (1996) stated three main characteristics of gifted students as;

\section{a) Precocity}

Gifted children are precocious when given the opportunity to use their gift or talent as well as they learn more quickly and easily than typical children. They begin to master an area earlier than their peers. Learning in their domain is more effortless for them than for children who are not gifted. In most instances, children who are gifted are precocious because they have an inborn high ability in a particular domain or domains, although this inborn precocity must be identified and nourished.

b) Marching to their own drummer

Learn in a qualitatively different way than children who are not gifted. One way they march to a different drummer is that they require less support or scaffolding, from adults to learn than their nongifted peers do. Often, they resist explicit instruction. They also often make discoveries on their own 
and solve problems in unique ways within their area of giftedness. They can be normal or below normal in other areas.

c) A passion to master

Driven to understand the domain in which they have high ability. They display an intense, obsessive interest and an ability to focus. They are not children who need to be pushed by their parents. They frequently have a high degree of internal motivation.

However, the characteristics of giftedness endorsed by the parents were compiled as part of a study carried out by Silverman (1973) on 241 exceptionally gifted children. The children ranged in age from 2.5 to 12.5 years. The sample consisted of 112 girls and 129 boys. The following characteristics were endorsed by 90 percent of the parents of this group were learns rapidly, extensive vocabulary, excellent memory, reasons well, strong curiosity, mature for age, good sense of humor, keen observation, compassion for others, vivid imagination, long attention span, ability with numbers, concern with justice and fairness, sensitivity and wide range of interests.

\section{Origin and Cause of Gifted Children}

Basically, it has been widely agreed that both genetics and environment play a role in determining giftedness, but their relative importance is still being debated. Some believe that giftedness may be due to some innate process which is independent from the environmental effects. This means that regardless of where the child is raised, a gifted child will demonstrate the gifts at some point. For example, there are numbers of children with extraordinary gifts that could have an innate basis, such as the musically gifted. However, giftedness is also linked to the biological claim such as the brain or a chromosome that people believe scientists have yet to find. Psychologically, giftedness is believed to be a gift that has a genetic origin and is at least partly innate which may not be clear at an early stage but rather an inclination that the child possesses the gift.

Indirect evidence indicates that gifted children and savants have a typical brain organization which is the result from genetic or environmental factor. First, giftedness in mathematics, visual arts, and music is associated with superior visual-spatial abilities, and children with mathematical gifts show enhanced brain activity in their fight hemisphere when asked to recognize faces, a task known to involve the fight hemisphere (O'Boyle et al., 1991). Studies have indicated that individuals with extremely high mathematical abilities have frontal lobes of the brain which are more differentiated compared to average students. Neuropsychological studies claim that in information processing, gifted individuals have enhanced brain activity localized in the right hemisphere. This does show to a certain extent that the physical characteristics of the brain may be associated to an innate process in which certain people obtain high levels of gifts and capabilities in different areas. Many studies have proved that demonstrated giftedness is subjected to biological (nature) and sociological (nurture) factors. These are again all linked to several other external factors outside of the child's physiological makeup. In short, to be considered gifted, a child needs to have the right biological make up (genes, brain structure) and environment (education, exposure, diet, emotional security) to enhance and bring out the gifts.

In addition, gifted children have a deep intrinsic motivation to master the domain in which they have high ability and are almost manic in their energy level (Winner, 1996). However, research on the nurture hypothesis has failed to demonstrate that giftedness is a product of hard work and intensive training or that any family environment causes giftedness. Nonetheless, the research just reviewed has implications for the nurturance of giftedness. There is no research has demonstrated that hard work, perseverance, and practice is sufficient to explain the existence of giftedness. Hence, these qualities have been shown to be necessary for high achievement because we have no documented cases of high achievement reached in the absence of long training and many cases showing the association of high achievement with training (Winner, 2000). 


\section{Methodology}

This study is a qualitative study using content analysis design. Qualitative content analysis involves a process designed to consolidate raw data into categories or themes based on valid conclusions and interpretations. This process uses inductive reasoning, in which themes and categories emerge from the data through careful examination and constant comparison of the researcher. The main purpose of content analysis is to identify important themes or categories in the content, and to provide a rich picture of the social reality created by the themes or categories. In this study, researchers used resources from journal articles focused on smart and talented students. Selected articles were obtained from the university database, Academic Search Premier@EBSCOhost, which was published from January 2010 to January 2021. However, former articles which significant to this study are also referred.

Researchers use specific keywords such as definitions, characteristics and challenges faced by gifted and talented students. In addition, the researcher also identified other emerging words or phrases (such as the stress of untalented students) and analyzed the meaning behind each of the concepts to better understand the issues discussed. The researcher has set out to select only articles that are in the form of academic journals, have references and articles that have been evaluated by other researchers scientifically. Moreover, in order to ensure the reliability and credibility of the study results, the researcher evaluates the data obtained by identifying whether there are similarities in and differences between the resulting categories. Articles in the form of proceedings, incomplete, non-downloadable and unrelated to the scope of the study will not be selected. Finally, the researchers selected 40 articles that met the research questions. This is done by reading, analyzing and structuring relevant content according to the topic of literature review. Subsequently, selected articles are categorized according to the scope of the study to gain a better understanding, on the issue of smart and talented students.

\section{Result and Discussion}

\section{Issues and Challenges of Gifted Children}

Basically, there are possible problems that are associated with the characteristics of gifted and talented children. Lack of understanding by parents, educators, and health professionals combined with the problem situations leads to interpersonal problem which are then mis-labeled. In a more recent report, it was estimated that the rate of social and emotional difficulties experienced by profoundly academically gifted children is about twice the rate found among the non-gifted, with almost a quarter of such children having such difficulties. Extreme levels of giftedness lead to isolation. Hence, in middle childhood profoundly gifted children may try to hide their abilities in the hopes of becoming more popular (Winner, 2000).

It has been put forth by many studies that gifted and talented children are put differences in many areas in comparison with normal developing children starting from an early age. Most of gifted and talented children display superior in metacognitive skills, memory enables them to learn faster and solve complex problems, remember the tiniest details, command of language, skills in visual and performance arts. Despite the strength that gifted and talented children have, they also experiencing internal pressures and conflicts that limit their social and emotional development (Amnah et al., 2017).

\section{Social and emotional development}

In the learning environment, various research findings conclude that gifted and talented children are burdened with social and emotional issues that affect psychological well-being and emotional stability (Hamizah, Rashid \& Zaliridzal, 2021; Abu Yazid \& Noriah, 2016). They often face intrapersonal and interpersonal conflicts both within and outside the learning environment, tend to isolate themselves and lack tolerance with peers, have high anxiety traits, lack motivation to learn, have difficulty in accepting criticism, often feel depressed, as well as depression (Abu Yazid \& Noriah 2016; Noriah \& Abu Yazid 
2010; Wood 2010). The uniqueness of gifted and talented children's personalities also causes most of them to feel frustrated and that frustration is translated into reactions showing boredom as well as behaviors that disrupt the entire learning process (Abu Yazid \& Noriah, 2016).

The gifted and talented children are also associated with uniqueness in terms of behavior and more advanced abilities to differentiate them from other peers (Rafidah, 2014). Due to the characteristics of maturity shown enable them to be able to provide thoughtful ideas in debating certain issues. This situation makes them have a more advanced level of morality in addition to a spirit of sensitivity to idealism, making them look perfect in the eyes of society. Nevertheless, the nature of this idea is actually the pain and misery faced by this group that ultimately makes them feel sadness, anger and depression (Ryan, 2001).

Apart from that, they are unique in their social and emotional aspects which motivate them to hide their problems or internal conflicts. They are also having difficulty asking for help or assistance from others in solving problems (Rafidah, 2014). This is because they are more likely to struggle on their own in overcoming problems or conflicts which in the end make it difficult for themselves to be understood by others (Khatena, 1992). This situation is one of the factors in the gifted and talented children facing various problems in life, especially those related to social and emotional needs that are unique and different from typical children (Dimitrios, 2020). Therefore, it is vital for teachers and parents to understand how the gifted and talented children cope with this conflict as coping strategies is the process needed by a person in adapting to oneself as well as the environment in life to achieve desired needs and goals (Rashid et al., 2020)

From the aspect of career development, many studies have found that gifted and talented student has problems related to career direction due to multipotentials, lack of information, lack of guidance and other supporting factors (Abu Yazid \& Noriah, 2016). For example, this potential diversity refers to the ability of gifted and talented children to excel in various fields which puts them in a dilemma in determining career choices. The effect causes delays in making career choices, often changing direction or choices without making any deep consideration.

Furthermore, according to Renzulli (1997) gifted and talented children also has better and higher intellectual, sensual, psychomotor, imaginative and emotional levels than normal students in addition to extraordinary cognitive abilities, creativity and commitment. As such, gifted and talented children have high emotional sensitivity and awareness and shows extreme empathy towards others. Thus, there are times when these students face difficult situations in adjusting to a new environment, easily feel bored and lonely and face various kinds of complex emotions. Research by Neihart, Reis, Robinson and Moon (2002) also found that gifted and talented children experiences social and emotional problems such as frustration, irritability, anxiety, boredom, strong social isolation, stress, stress, difficulty making friends because of advanced concepts of friendship, lack of motivation, low selfconcept, social rejection, loneliness, phobias, interpersonal problems, extreme perfection, lack of resilience, fear of failure and risk aversion due to desire for perfection and depression.

\section{Needs of Guidance and Counseling Services}

Many studies in Malaysia have found that guidance and counselling services are very much needed by gifted and talented students (Amnah et al., 2017; Diani et al., 2017; Rafidah \& Noriah, 2014; Abu Bakar \& Noriah, 2010). This is because most of them are lacking in decision making skills (Hamizah, Rashid \& Hafizah, 2020) which if this skill is not being honed continuously it will further cause disturbance in their social and emotional state. However, most gifted and talented students who seek counseling do not express issues related to psychological problems encountered as non-gifted ones. Those who attend are only to seek counselling on career issues or to seek advice in relation to academic issues only (Abu Yazid \& Noriah, 2016). This clearly shows that they are not prepared to express issues related to their unique psychological aspects and indicates that they need special approaches than normal students. 
Therefore, in giving the effective services toward gifted and talented children, counselors need to understand their strengths and challenges. Thus, counselors must prepare themselves with knowledge, especially on the social and emotional development of gifted and talented children and also empowering counselling skills (Walker, 1982). In this regard, guidance and counseling services need to act proactively in an effort to foster the development of counseling for gifted and talented children by offering services that are different from ordinary students. As suggested by Rosselet \& Stauffer (2013) and Mahoney, Martin \& Martin (2003), creative approach should be applied in helping gifted and talented children by taking into account the uniqueness of their effective and cognitive development of these students that have a high level of intellectual, creativity (Rorlinda et al., 2016), imagination, fantasy, sensitivity (Rosselet \& Stauffer, 2013; Sak, 2004).

\section{Teachers' stigma towards gifted students}

Gifted students differ from their peers because they learn more easily and in a shorter time, think at a more abstract level, engage with interest in topics they enjoy until they master them, and are able to direct their attention to multiple simultaneous activities (Winebrenner, 2000). However, they may face learning and socioemotional problems while in regular classes that require educational interventions such as gifted classes or other programs that meet their needs. Teachers often feel afraid to teach gifted and talented students because they have the impression that gifted students have excellent abilities and vast knowledge, but they are also arrogant and critical as well as know better than teachers and also easily get bored. This stigmatic thinking among teachers does not help the gifted children to excel and unleash their potential. This teachers' attitudes to gifted students can be changed if the school provide appropriate training for teachers to teach those students (Gross, 2016).

\section{Negative peer attitudes}

Being labeled as gifted comes with it the risk of being stigmatized by others, especially among peers. Most research focus on the other people's negative attitudes toward gifted population. Gifted people overestimation of others' negative responses toward them may shape their behavior more than other people's actual responses. Therefore, the gifted individuals struggle' with contradictory feelings. While they recognize and appreciate their unique abilities, they are concerned about the social stigma that such abilities may stimulate. On the other hand, some might socially adjust and can be accepted by their peers. Some of them might faces conformity pressures. They might hide their talents in order to be accepted and conform to the peer expectation resulted on developing frustrations, anxiety and depression and resistance to authority (Wright-Scott, 2018). Educators, especially counselors and school psychologists should be able to recognize and respond to the struggle experienced by gifted adolescents in coming to terms with their own giftedness and try to increase their social skills.

\section{Perfectionism}

Perfectionism is defined as "the striving for flawlessness" (Flett \& Hewitt, 2002). Perfectionism ca be healthy and unhealthy. Unhealthy perfectionism leads to the fear of failure and never feel satisfied with their performance because it is never good enough. Meanwhile, healthy perfectionism refers to those who are able to enjoy their work, recognize their limitations on performance, and are motivated to achieve perfection out of the striving for excellence. Unhealthy perfectionism correlated to negative outcomes such as anxiety, depression, and low self-esteem. Researchers found mix findings on perfectionism among the gifted students. Gifted students experiencing unhealthy perfectionism have high levels of anxiety, are highly concerned about making mistakes, and perceive pressure from others to achieve perfection. Therefore, students need to learn that self -expectations and those of others can influence their thinking and behavior. It is also important to help students value their own efforts to achieve excellence through efforts. An affective curriculum aimed at helping gifted adolescents reduce unhealthy aspects of perfectionism and developing a more positive coping approach is needed to promote healthy social and emotional growth (Mofield \& Chakraborti-Ghosh, 2010). 


\section{Conclusion}

In many children, a pattern of gifted behaviors and/or advanced performance can be seen as early as pre-school; however, classroom modifications for gifted students altering the pace, depth, or complexity of instruction are rarely implemented in pre-school and early elementary classrooms (Robinson et al., 2002). Thus, the early educational experiences of many young gifted children provide limited challenge and hinder their cognitive growth rather than exposing learners to an expansive, engaging learning environment. This problem may be intensified among traditionally underserved populations of young gifted students including culturally, linguistically, and ethnically diverse learners, as well as children from poverty because in many cases additional resources for providing enriched learning experiences in homes and communities are also limited (Robinson et al., 2002). Usually, of every 100 children, at least two can be classified as outstandingly high in intellectual, creative or social ability. Giftedness knows not creed, color or class. The gifted learn quickly. As infants, gifted children pass the early milestones rapidly, talking early and learning to read before starting school. They have a thirst for knowledge of unusual subjects and ask questions with insatiable curiosity. Gifted children find themselves out of step with their contemporaries. Some have no difficulty, but others find themselves isolated and rejected by their peers. They may withdraw into themselves and have only a few friends. They may be bored with their schoolwork and become frustrated and discouraged. They may deliberately underachieve to make themselves unacceptable to their classmates. Unless carefully nurtured, some will drop out from society and may even turn their talents to delinquency and crime (NAGC, Malaysia).

\section{References}

Abdul Rashid Abdul Aziz, Amin Al Haadi Shafie, Umi Hamidaton Mohd Soffian Lee \& Raja Nur Syafiqah Raja Ashaari. (2020). Strategi Pembangunan Aspek Kesejahteraan Kendiri bagi Mendepani Tekanan Akademik Semasa Wabak COVID-19. Malaysian Journal of Social $\begin{array}{lllll}\text { Sciences and Humanities } & \text { (MJSSH), 5(12), } & 16 & -\end{array}$ https://doi.org/https://doi.org/10.47405/mjssh.v5i12.594

Abu Yazid, A. B. \& Noriah, M.I. (2010). Counselling Issues of Gifted Students Attending a School Holiday Residential Program: A Malaysian Experience. Procedia - Social and Behavioral Sciences, 7(C), 568-573.

Abu Yazid, A. B. \& Noriah, M.I. (2016). Pendidikan Pintar dan Berbakat Di Malaysia. Bangi: UKM.

Abu Yazid, A.B. \& Aliza, A. (2009). Sokongan psikologikal dan sosio-emosi pelajar pintar cerdas. Dlm. Noriah M.I., Rosadah A.M. \& Siti Fatimah M.Y.(pnyt.), PERMATA pintar: Pengalaman $U K M$. Bangi: UKM.

Amnah Zanariah, A. R., Amirah, Z., Nur Fazidah, S.M. (2017). Kajian Tentang Perfectionism dan Stail Berfikir Pelajar Muslim Pintar dan Berbakat di Malaysia. International Journal of Islamic Studies, 6(2), 13-22.

Blaas, S. (2014). The Relationship Between Social-Emotional Difficulties and Underachievement of Gifted Students. Australian Journal of Guidance and Counselling, 24(02), 243-255.

Buckner, C. (2009). Gifted First Graders in A Multi-ability Classroom: An Interpretive Case Study. [All Graduate Theses and Dissertations]. Paper 300. Retrieved on April 28, 2013 from http://digitalcommons.usu.edu/etd/300

Cheng, P.W. (1993). Metacognition and Giftedness: The state of the relationship. Gifted Child Quaterly, 37, 105-112.

Clark, B. (2002). Growing up Gifted ( $5^{\text {th }}$ ed.). Columbus: Charles E. Merrill.

Delisle, J. (1985). The eight great gripes of gifted kids: Responding to special needs. Roeper Review, $8(11), 15-17$.

Dimitrios, P. (2020). Psychological Framework for Gifted Children's Cognitive and Socio-Emotional Development: A Review of the Research Literature and Implications. Journal for the Education of Gifted Young Scientists, 8(1), 305-323.

Fisher, E. S. \& Kennedy, K. (2016). Counseling Diverse Populations in Schools. New York: Oxford University Press. 
Flett, G. L., \& Hewitt, P. L. (2002). Perfectionism and maladjustment: An overview of theoretical, definitional, and treatment issues. In G. L. Flett \& P. L. Hewitt (Eds.), Perfectionism: Theory, research, \& treatment (pp. 5-31). Washington, DC: American Psychological Association.

Gallagher, J. J. \& Gallagher, S. A. (1994). Teaching The Gifted Child. (4 ${ }^{\text {th }}$ ed.). Boston, MA:Allyn.

Hollingworth, L. S. (1942). Children above 180 IQ; Stanford-Binet origin and development. New York: World Book.

James, T.W., Edward, R.A., Nadia, E.W., J, G., Paul, B.F., \& Richard, O. (2004). Abstracted from Misdiagnosis and Dual Diagnosis of Gifted Children and Adults: ADHA, Bipolar, OCD, Asperger's, Depression, and Other Disorders. Scottsdale: Great Potential Press.

Katja Košir, Marina Horvat, Urška Aram \& Nina Jurinec. (2015). Is being gifted always an advantage? Peer relations and self-concept of gifted students, High Ability Studies, DOI: 10.1080/13598139.2015.1108186

Khatena, J. (1992). Gifted: Challenge and Response for Education. USA: F.E Peacock Publisher.

Mahoney, A., Martin, D. \& Martin, M. (2003). Gifted identity formation: A therapeutic model for counseling children and adolescents. In. J. Plucker \& C. Callahan (Eds.), Critical issues and practices in gifted education: What the research says. hlm 199-229. Waco, TX: Prufrock Press.

McEachern, G.A. (2001). Gifted Students with Learning Disabilities: Implications And Strategies For School Counselors, Professional School Counseling, 5(1), 17-24.

Mofield, E.L., \& Chakraborti-Ghosh, S. (2010). Addressing Multidimensional Perfectionism in Gifted Adolescents with Affective Curriculum. Journal for the Education of the Gifted, 33(4), 479513.

National Association for Gifted Children Position Statement. (2006). Creating contexts for individualized learning in early childhood education. Retrieved April 1, 2013, from http://www.education.com/reference/article/Ref_Early_Childhood_2/

Neihart, M., Reis, S. M., Robinson, N. M., \& Moon, S. M. (2002). The social and emotional development of gifted children: What do we know? Waco, TX: Prufrock Press.

Nor Hamizah Ab Razak, Abdul Rashid Abdul Aziz \& Mohd Zaliridzal Zakaria (2021). Validity of Cognitive Behaviour Play Therapy Module (DBPT Module). Malaysian Journal of Social Sciences and Humanities (MJSSH), 6(3), 396 400.https://doi.org/https://doi.org/10.47405/mjssh.v6i3.726

Nor Hamizah bt Ab Razak, Abdul Rashid Aziz \& Nurhafizah Mohd Sukor (2020). Hubungan antara Kemahiran Membuat Keputusan dan Daya Tahan dalam kalangan Pelajar Pintar Berbakat. Malaysian Journal of Social Sciences and Humanities (MJSSH), 5(12), 333 - 341. https://doi.org/https://doi.org/10.47405/mjssh.v5i12.601

O'Boyle, M. W., Gill, H. S., Benbow, C. P., \& Alexander, J. E. (1994). Concurrent finger-tapping in mathematically gifted males: Evidence for enhanced right hemisphere involvement during linguistic processing. Cortex, 30, 519-526.

Rafidah Kastawi \& Noriah Mohd Ishak. (2014). Terapi seni dalam kaunseling pelajar pintar dan berbakat. Malaysian Journal of Youth Studies, 8(6), 147-166.

Renzulli, Joseph S. \& Reis, Sally M. (1997). The Schoolwide Enrichment Model. (2 ${ }^{\text {nd }}$ ed.). Creative Learning Press: Mansfield.

Robinson, N. M., Lanzi, R. G., Weinberg, R. A., Ramey, S. L., \& Ramey, C. T. (2002). Factors associated with high academic competence in former Head Start children at third grade. Journal of Gifted Child Quarterly, 46, 281-294.

Rorlinda, Y., Noriah, M. I., Azizah, M.Z., Siti Noor Diana, M. K. (2017). Personal Identity and SocioEmotional Issues among Malaysian Gifted and Talented Students, Jurnal of Social and Behavioural Sciences, XIX: 2423-2440.

Rorlinda, Y., Noriah, M.I., Siti Aishah, H. \& Afifah, M.R. (2016). Kajian Jati Diri dan Tekanan Isu Sosio-Emosi dalam Kalangan Pelajar Pintar dan Berbakat. Jurnal Psikologi Malaysia, 30(2), $42-60$.

Rosadah Abd Majid. (2004). Satu Kajian Perbandingan Profil Pelajar Pintar Cerdas Akademik dengan Pelajar Sederhana Akademik. [Tesis Dr. Fal]. Universiti Kebangsaan Malaysia.

Rosselet, J. G. \& Stauffer, S. D. (2013). Using Group Role-Playing Games with Gifted Children and Adolescents: A Psychosocial Intervention Model International. Journal of Play Therapy, 22(4), 173-192. 
DOI: https://doi.org/10.47405/mjssh.v6i4.760

Ryan, J. J. (2001). Specialized counseling: the social-emotional needs of gifted adolescents. Tempo Newsletter, 21(1), 17-18.

Sak, U. (2004). About Creativity, Giftedness and Teaching the Creatively. Roeper Review, 26(4), 216222.

Silverman, L.K. (1997). The Construct of Asynchronous Development. Peabody Journal of Education, 72, 36-58.

Winner, E. (2000). The Origins and Ends of Giftedness. American Psychologists, 55(1), 159-169.

Winner, E. (1996). Gifted children. New York: Basic Books.

Wood, S. (2010). Best practices in counseling the gifted in school: What's really happening. Gifted Child Quarterly, 54 (1), 42-58.

Wright-Scott, K.A. (2018). The Social-Emotional Well-Being of the Gifted Child and Perceptions of Parent and Teacher Social Support. [Unpublished Doctoral Thesis]. Queensland University of Technology. 